\title{
Enviroment Knowledge Implementation to Senior High School and Collage Students Activities
}

\author{
Nita Noriko ${ }^{1}$ \\ ${ }^{1}$ Departement of Biology, Faculty of Science and Technology, University of Al Azhar Indonesia, \\ Jl. Sisingamangaraja, Kompleks Masjid Agung Al Azhar, Kebayoran Baru, Jakarta Selatan 12110 \\ Author of oresspondence/Email: nita_noriko@uai.ac.id
}

\begin{abstract}
Al Qur'an is the word of Allah SWT as the rules and guidance to get harmony and success life in here and after. The explanation and ways how to implement command of Al Qur'an are found in Al Hadist Muhammad SAW. Al Qur'an teaches may aspect of life and one of them is how using and managing the natural resources and conserve of environment, using the source of energy, water, health and sanitation. In the other hand the people of the world included Indonesia facing environment problem. Sustainable Development Goals (SDGs) from United nation are collected of 17 global goal or agenda 2030 for transforming our world 2030 and containing strategy to solve environment problem. Base on the fact, the problem is how awareness the senior high school and higher education (university) students specially Islamic students to contribute conserve the environment?. The goals of the research were to know how environment awareness and action performance of students from senior high school and university. Methodology of the research was survey and observation concerning in 320 student from 4 senior high schools and in 1 university. The result of the research showed $41,5 \%$ of natural and $40.35 \%$ social science students from Islamic values senior high schools (SMAI IPA and IPS) showed the awareness action to environment. In SMAN IPA students showed their awareness $51.1 \%$ and SMAN IPS 20.6\% Based on observation students from university with Islamic values showed low awareness of environment.
\end{abstract}

Keyword - Al Qur'an, Awareness, Environment, Hadist, Students

\section{INTRODUCTION}

$\mathrm{I}$ ndonesia is an archipelagic geographic country with 17.503 islands which lies in Pacific Ring of 1 Fire along northeastern island adjacent to an including New Guinea and the Alpide belt along south and west from Sumatera, Java and the lesser Sunda, Bali, Flores and Timor by the consequences numerous active volcanoes releasing mineral giving benefit for supporting plant growth. The other hand Indonesia passed equator with tropical climate. This condition make Indonesia has many natural ecosystem such as costal 54.716 kilometer, estuarial, marine, sea grass, rain forest (225 million acre) it means $57 \%$ of the land, monsoon and huge biodiversity corral reef, mangrove, flora and fauna is a mixture Asia and Australia. The endanger animals such as Sumatera Tiger, Rhinoceros, Anoa, Orang Utan, endemic and endanger flora species such as Aghatis labillardieri plant from Papua with 2 meter diameter and 60 meters height, Raflesia arnoldi is the largest individual flowering plant in the parasite genus live in indonesia rain forest tropis. Indonesia has 8 UNESCO Heritage site and 3 of them have special ecosystem there are Komodo and Bunaken National Park and Raja Ampat Island having highest recorded level of diversity in marine life [1].

Growing the population in Indonesia and rapid industrial development make Indonesia facing 3 prominent problem related with environment. There are pollution in air, water and land, scarce of fresh water especially in the cities, and loss of biodiversity. Traffic congestion, illegal home industry and inadequate garbage management are source of dominant factors caused of air pollution. Air pollution show significant related with decreasing water and land quality. For the example acid rain from sulfur dioxide, nitrogen oxide, carbon dioxide there are industrial and transportation emission. Those molecules will make reaction with water in atmosphere and produce acid rain. It is the threat on food chain [2] in ecosystem and 
biodiversity in forests, freshwaters, soil fertility, insect, bacterial and fungi in the soil, aquatic life, corrosion and weathering of the building. Source of land pollution also caused by not reasonable using of fertilizer chemical, herbicide and pesticide and give the impact to river. Illegal home industry also a threat of ecosystem because usually they throw away their waste to river. Scarcity of fresh water not only caused by pollution but also by lack of catchment area for water retention as consequences of so many the people housing area as impact on explosion of the population numbers.

To solve the problem of environmental degradation and natural resources Indonesia government has policy and agenda Long Term Development Plan 25 years 2005-2030 It is correlation with Sustainable Development Goals are collection 17 global goal or agenda 2030 for transforming Our World 2030. Implementation of agenda 2030 needs commitment, awareness and sense of belonging all the people with respect to natural resources and environment. There are important factors to build the nation with sustainable development paradigm. Education is one attempt to develop mind set and capacity building of the human resources.

\section{METHOD}

The research using survey and observation method to measure awareness about environment specially aspect knowledge and action/performance. Respondents were collected from Islamic and Government Senior High School wich consist of social and science group.Total respondents were 320 students. Teachers respondents who teach the natural and social science. In order to observe, its implementation among higher educated people, the research also conducted for Islamic College Students in Jakarta based on data collection from period 2018. Observed their action to protect schools environment. was conducted every days for 10 day. The parameter of environment knowledge and action to protect environment for students and teachers were air, water, pollution, waste, plant and soil such as on Table 1. Location the research was conducted in Jakarta and Bekasi on 2007

\section{RESULT AND DISCUSSION}

Environment education in 2 Islamic Senior High Schools students in Jakarta specially on knowledge to environment the students showed good achievement. Based on data SMAI IPA students showed $79.02 \%$ and SMAI IPS $62.65 \%$ have known values existences of ecosystem and biodiversity for life, global warming effect and climate change, and also effect of pollution hazard. SMAN IPA students have known about environment knowledge $95.05 \%$ and SMAN IPS students $90.5 \%$. There were evidence that all of the teachers have good knowledge and teach them about environment issue such global warming and climate change. In the fact of the research showed all teachers have known about environment issue. The teachers indicated awareness and good action to protect environment. Analysis result of national curriculum in Senior High School indicated loaded with environment issue.The application of implemented environment knowledge showed several action (Table 1 and 2).

Table 1. The material containing in senior high schools curriculum 2007 in Indonesia

\begin{tabular}{|c|c|c|}
\hline No & Knowledge & Action \\
\hline 1 & $\begin{array}{l}\text { How to manage } \\
\text { the fresh water }\end{array}$ & $\begin{array}{l}\text { Efficient using the } \\
\text { fresh water, make } \\
\text { sure swich off the } \\
\text { tap water after using }\end{array}$ \\
\hline 2 & $\begin{array}{l}\text { How to protect } \\
\text { the air from } \\
\text { pollution }\end{array}$ & No smoking \\
\hline 3 & $\begin{array}{l}\text { How to manage } \\
\text { the waste and } \\
\text { garbage }\end{array}$ & $\begin{array}{l}\text { Reduce, reuse, } \\
\text { recycle and } \\
\text { composting }\end{array}$ \\
\hline 4 & $\begin{array}{l}\text { How to } \\
\text { conserve the } \\
\text { environment }\end{array}$ & $\begin{array}{l}\text { Throw the garbage } \\
\text { in the basket }\end{array}$ \\
\hline 5 & $\begin{array}{l}\text { Source of } \\
\text { pollution }\end{array}$ & $\begin{array}{l}\text { Not make noise and } \\
\text { put the in the trash }\end{array}$ \\
\hline 6 & $\begin{array}{l}\text { Efective using } \\
\text { electrical } \\
\text { energy }\end{array}$ & $\begin{array}{l}\text { Swicth of the lamp } \\
\text { and air condition } \\
\text { when left the room }\end{array}$ \\
\hline
\end{tabular}

Survey about learning methodology in the class showed the teachers often discuss about sustainable development concept with many interesting topic such us about scarce of fresh water, deforestation, soil degradation, greenhouse gas effect on global warming, illegal logging. Beside that the teachers teach increasing impact of population and urbanization from social, economic and ecology perspective. Learning process not only in the class but also the students looking directly on the object when they field studied. 
Table 2. Comparison of material containing between science and social science in senior high schools curriculum in Indonesia 2007

\begin{tabular}{|c|c|c|}
\hline No & $\begin{array}{l}\text { Knowledge Of } \\
\text { Natural Science }\end{array}$ & $\begin{array}{l}\text { Knowledge of } \\
\text { Social Science }\end{array}$ \\
\hline 1 & $\begin{array}{l}\text { Ecology Aspect : } \\
\text { water, land, air, } \\
\text { energy, } \\
\text { organisme, } \\
\text { interaction }\end{array}$ & $\begin{array}{l}\text { Ecology from } \\
\text { geographyc aspect }\end{array}$ \\
\hline 2 & $\begin{array}{l}\text { Limmited of } \\
\text { Natural Resources }\end{array}$ & $\begin{array}{l}\text { Economic and } \\
\text { social effect on } \\
\text { limmited of natural } \\
\text { resources }\end{array}$ \\
\hline 3 & $\begin{array}{l}\text { Renewable and } \\
\text { Unrenewable } \\
\text { Energy }\end{array}$ & $\begin{array}{l}\text { Economic and } \\
\text { social effect on } \\
\text { renewable and } \\
\text { unrenewable } \\
\text { energy }\end{array}$ \\
\hline 4 & $\begin{array}{l}\text { Pollution effect } \\
\text { on health }\end{array}$ & $\begin{array}{l}\text { Polution effect on } \\
\text { economic and } \\
\text { social }\end{array}$ \\
\hline 5 & $\begin{array}{l}\text { Global warming } \\
\text { effect on health }\end{array}$ & $\begin{array}{l}\text { Global warming } \\
\text { effect on social } \\
\text { and economic }\end{array}$ \\
\hline
\end{tabular}

Contrary condition on action parameter to protect environment in SMAI IPA students. Only $44.65 \%$ of them showed action aware to environment and $40.03 \%$ for SMAI IPS students. SMAN IPA students showed their awareness $51.1 \%$ and SMAN IPS $20.6 \%$ (Figure 1). Data show significant difference between groups $0.001 \mathrm{p}<0.05$. It means that totally students from SMAN IPA knowledge and action awareness about environment relatively more than SMAI IPA. Difference fact on SMAN IPS only $20.06 \%$ of students showed their action to conserve environment. SMAI students from social science more aware to environment compare SMAN students. It was influenced by implementation the Islamic teaching specially in surah Ar Rum 41 : Corruption has appeared through the land and sea by (reason of) what the hand of people have earned so He may let them taste part of the consequences of what they done that perhaps they will return to righteous.

Several action in daily action were the students throw away their garbage to the shelf, floor, and park and they did not aware the garbage surround of them. They did not warn their friends when put garbage in any place. The students also did not care to tap water when saw the water bailouts. They also did not care with energy and resources for the example put out the light when left the room. Usually their activity using property which made wasteful.

Data analysis showed no correlation 0.153 between knowledge environment and the environment awareness action.

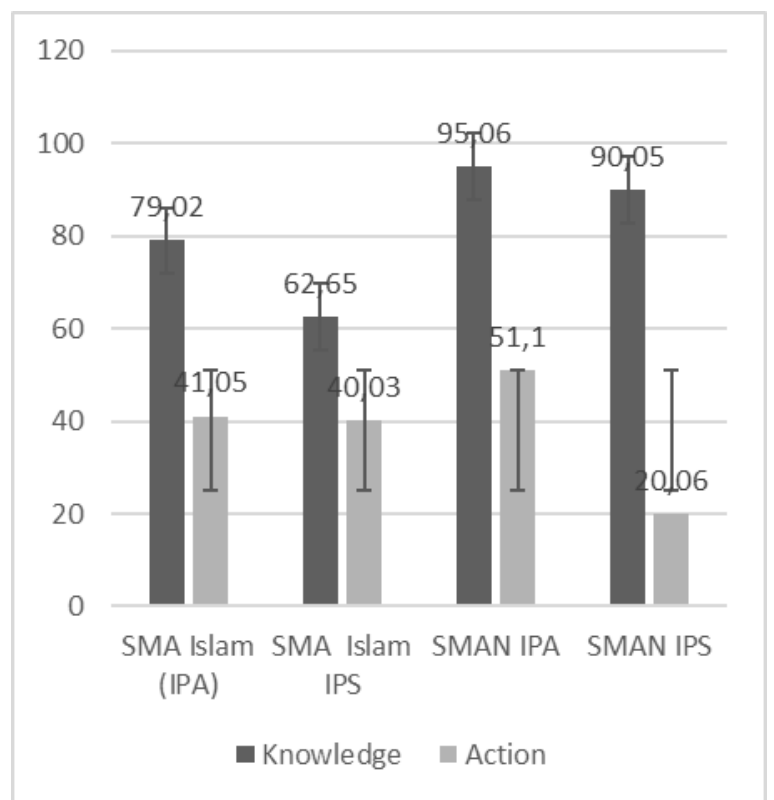

Figure 1. The students knowledge and action about environment awareness

All the situation indicated low of implementation application practice of environment knowledge in the students senior high school. This condition caused the schools did not seriously give attention implementation of environment awareness from elementary school. Generally the school did not apply punish and reward. The research found data that to enhance implementation awareness to environment in senior high school student influenced by school management. Principal dominantly influence to the school milieu awareness to environment. Principle whose concern, care, awareness to environment will support activity, make policy, rules, publication and collaboration with national and international institution for implementation environment education. On the other hand the research found $63.20 \%$ students from families in the middle social economic more aware compared high social economic. It caused in family in high social economic usually have maid. The action awareness students SMAI in 2007 is not different with students in an university with islamic values in 2018. Awareness and action to protect environment based on observation low implementation. For the example they throw away their garbage and the mineral water trace bottle in 
the floor. It caused by community habit do not aware to protect environment.

Based on result of the research Islamic values university has to concern about this condition and educated the student and make them aware and show the performance attitude to environment in daily activities. University is finally formal of education to build human resources capacity as next generation who expected and as important factor in sustainable development. Many program applied environment attitude in daily activity namely ecocampus. This methodology offer connectivity many knowledge such as ecology, technology, social and economic. Interdisciplinary enhance students capacity to development new concept and perspective [4]. Several activity could increase awareness environment of the students for the example the students and lecturer minimal using lift. This activity built awareness of electric energy and exercising for health. Activity made biopori in the event to increasing awareness necessary to saved of fresh water.

Manage of garbage by separating an organic and organic garbage. An organic garbage usually mineral water bottle and convert to another function and organic garbage convert organic fertilizer. Planting the tree in the campus park to aware global warming and deforestation. No areal smoking in campus to built awareness hazard of air pollution. Public service by coaching village to build sensitivity of environment problem in community. Increasing research about species endanger to build awareness of loss biodiversity, alternative local. Recycle of water ablution to increase awareness scarce of fresh water. Research and study about biodiversity and their benefit in ecosystem such as the turtle, endemic species for the example Pisang Barangan specially banana is only find in North Sumatera Indenesia, alternative source nutrition and likes kinds tubers and micro algae. Canna edulis Kerr (local name Ganyong) has potency as alternative food substitute of wheat flour containing prebiotic and antioxidant. Publication all awareness environmental activity and collaboration with national and international institution which concern to environment.

Based on education environment we hope could build commitment, awareness and sense of belonging all the people on natural resources and conduct of SDGs program. Connecting social and natural ecologies in ones curriculum and implemented in practical in community could increase young people contribute awareness [3]. Curriculum should integrate learning of fresh water to anticipate education agenda [5].

\section{CONCLUSSION}

Total students from senior high school Natural and social science showed awareness action to environment by their life style $38,60 \%$. University as the higher education should to concern about this condition by educated the students in many activities with oriented to ecocampus and public service.

\section{ACKNOWLEDGEMENT}

Thanks you very much for Universitas Al Azhar Indonesia (UAI) that give us opportunity to publish our article in procceding or scientific journal.

\section{REFFERENCE}

[1]. Wikipedia.org, Ring of Fire, Mediawiki,[online], Available: https://en.wikipedia.org/wiki/Ring_of_Fire , [Diakses pada Juli 2018].

[2]. Encyclopedia.com, Acid Rain, Information Plus(R) Reference Series Fall 2005, March 2019,Available : https://www.encyclopedia. com/science-and-technology/biology-andgenetics/environmental-studies/acid-rain. [Diakses pada Maret 2019].

[3]. T. Neilsen, and Jeniver, Connecting Social and natural ecologies thought a curriculum of giving for student wellbeing and engagement. Australian Journal of Education Environment, [online], Vol 34, Issue 3, pp 215-277, October 2018. Available: https://doi. Org/10.1017/aee.2018.41

[4]. T. Esther and H. J. So, Role of environmental interaction in interdisciplinary thinking: from knowledge resorve perspective. The Journal Environment Education. Vol 0, No 0, 1-21, 2018. Available:10.1080/00958964.2018. 1531280

[5]. A. Sammel, D. McMartin, K.Arbuthonoid, Education agenda and resistance with teaching and learning of freshwater and extreme freshwater, Australian Journal of Enviromental Education, Vol 34 issue 1, April 2018 